\title{
Family-centered care in a pediatric intensive care unit: professionals' perceptions
}

\author{
Cuidado centrado na família em unidade de terapia intensiva pediátrica: percepção dos \\ profissionais
}

Allana de Andrade Sampaio ${ }^{1}$, Jaqueline Brosso Zonta ${ }^{2}$, Fernanda Yeza Ferreira ${ }^{2}$, Aline Cristiane Cavicchioli Okido ${ }^{2}$

\begin{abstract}
Objective: to identify the professionals' perception regarding family-centered care. Methods: this is a crosssectional descriptive study with 60 professionals from a pediatric intensive care unit. The Brazilian FamilyCentered Care Perception instrument was applied. Data were analyzed using descriptive and analytical statistics, Student's t-test and Mann-Whitney test were used to compare variables. Results: the mean of the familycentered perception of care was $2.93( \pm 0.27)$, the median of 2.90 , a maximum score of 3.50 and minimum of 2.30. Most professionals (60.0\%) considered that family-centered care is sometimes practiced. The mean scores did not have statistically significant differences between the characterization variables of the team. Conclusion: perception of care distant from the recommendations of an extended care that aggregate the child and his family. Descriptors: Pediatric Nursing; Child; Family; Critical Care.
\end{abstract}

Objetivo: identificar a percepção dos profissionais com relação ao cuidado centrado na família. Métodos: estudo descritivo transversal com 60 profissionais de uma unidade de terapia intensiva pediátrica e aplicou-se o instrumento Percepção do Cuidado Centrado na Família-Equipe versão brasileira. Os dados foram analisados a partir da estatística descritiva e analítica, utilizou-se o teste t-Student e o teste de Mann-Whitney para comparação entre as variáveis. Resultados: a média do escore de percepção do cuidado centrado na família foi $2,93( \pm 0,27)$, mediana de 2,90 , escore máximo de 3,50 e mínimo de 2,30 . A maioria dos profissionais $(60,0 \%)$ considerou que o cuidado centrado na família às vezes é praticado. Os escores médios não apresentaram diferenças estatisticamente significantes entre as variáveis de caracterização da equipe. Conclusão: percepção de cuidado distante das recomendações de um cuidado ampliado que agrega a criança e sua família.

Descritores: Enfermagem Pediátrica; Criança; Família; Cuidados Críticos.

\footnotetext{
${ }^{1}$ Hospital das Clínicas, Universidade de São Paulo. Ribeirão Preto, SP, Brazil.

${ }^{2}$ Universidade Federal de São Carlos. São Carlos, SP, Brazil. 


\section{Introduction}

When referring to the children who present demands of continuous and long-term care in the health sectors, there are several denominations coexisting. Among the denominations that the literature presents, there are: children with special health needs - corresponding to those who are clinically fragile, in chronic and/or disabling health conditions ${ }^{(1)}$ and children with medical complexity - those who have Congenital or acquired multisystem diseases, requiring intensive care and may depend on technological devices ${ }^{(2)}$.

As a result of the fragile state of health, these children need frequent hospitalizations, including in an intensive care unit ${ }^{(3)}$. The International study indicates that a hospitalization is a traumatic event for the child and his family causing uncertainties and stress $^{(4)}$. In this perspective, hospitalization impacts beyond the biological dimension, as it triggers a series of family maladjustments, such as maternal overload, financial difficulties and sadness of healthy siblings ${ }^{(5)}$.

The intensive care unit aims to provide assistance to critically ill children from invasive and complex therapies. These units have a multidisciplinary team of doctors, nurses, nursing technicians, physiotherapists, among others. The process of hospitalization in an intensive care unit is seen as a stressful and traumatic phenomenon for both the child and the family, especially for the parents. In this perspective, it is necessary to establish a care that goes beyond technological knowledge and structured knowledge and running through the issues of attachment, acceptance, acceptability, and trust $\mathrm{t}^{(6)}$.

It is essential that the multidisciplinary team develop a differentiated care, encompassing the child and his family. To this end, the model of care centered on the patient and the family is an innovative and effective strategy in establishing a partnership between health professionals, family, and child(7). It is internationally recognized for being a model of care in which the family is an essential source of support and the main focus of attention is not the disease but the individual and his family ${ }^{(8)}$. It is based on the effective sharing of information, on unrestricted access to the child, on the effective participation of parents in decision-making, and on mutual respect ${ }^{(7)}$.

The literature reinforces that the incorporation of this practice in daily care leads to greater adherence to treatment and better results once a therapeutic alliance is formed between health professionals, the family, and the child, with respect, trust and empathy ${ }^{(9)}$. The reduction of hospitalization time and the increase in the parents' self-confidence to perform home care are among the main benefits, consequently reducing the number of readmissions ${ }^{(7,10)}$.

Therefore, this study is relevant for its potential in subsidizing changes in care practice, such as the implementation of strategies to raise awareness of the team with a view to attitudinal changes and consequent expansion of family participation in the care of hospitalized children in a pediatric intensive care unit.

Given the above, the general objective of this study was to identify the professionals' perception regarding family-centered care.

\section{Methods}

It is a descriptive study with a cross-sectional design $^{(11)}$. The investigation was carried out in a Pediatric Intensive Care Unit of a tertiary hospital in the interior of the state of São Paulo, Brazil, from July to August 2016. The criterion adopted for the selection of this service is because it is a pediatric intensive care unit of reference at the municipal and regional level.

Regarding the study participants, there was no sample selection, since the total population was considered. Thus, all the eligible members of the team participated in the study, totaling 60 professionals, with physicians, nursing staff, physiotherapists, and psychologists. The eligibility criterion was: to be a member of the multi-professional team for at least six months. The exclusion criterion was: professionals who were away from the care during the period of data collection. 
Initially, a contact was established with the unit to explain the project and request collaboration in the indication of eligible participants. After that, a previous contact was done with the professionals with the purpose of inviting them to participate in the research. The first contact was during working hours. However, the production of the empirical material occurred at a place and date defined by the research participants.

The following research instrument was used: Perception of Care Centered in Family-Team Brazilian version ${ }^{(9)}$. The instrument contains 20 questions, organized in three areas: respect, collaboration, and support. The respect domain includes items that recognize the rights of the family in the hospital, the domain collaboration refers to the recognition of parents as care partners and the support domain investigates the way the professionals support the family. The instrument also includes data identifying the professionals, including gender, age, education, time of work experience, among others. The mean time for application of the research instrument was 20 minutes. It is noteworthy that the application was conducted by a nurse/researcher previously qualified.

The previously coded data was launched in a formatted database in the Excel spreadsheet editor, by double typing. After validation, the database was exported to the Statistical Package for Social Science, in which descriptive and analytical statistical analyses were performed. In the descriptive phase, the categorical variables were presented by absolute and relative frequency, while the measures of central tendency, variability and position were used for the description of the numerical variables.

In the analytical phase, mean scores of family-centered care were compared between the independent variables using the Student's t-test and the Mann-Whitney test for the variables that did not present a normal distribution. A significance level of 5.0\% was used for the tests.

The average score of family-centered care perception among professionals, classified as numerical, was considered as a dependent or variable response.
The following variables were considered as independent: age in years; Education level; Time of experience and profession (categorical variables). It is noteworthy that, in the descriptive analysis, the perception of care centered in the family was also treated as a categorical variable following the recommendations of the instrument.

The study complied with the formal requirements contained in the national and international regulatory standards for research involving human beings.

\section{Results}

Sixty professionals participated in the study. They were nine nurses, 25 nursing technicians, 19 physicians, six physiotherapists and one psychologist. Regarding age and gender, $65.0 \%$ were older than 30 years old and $80.0 \%$ were female. Most professionals $(70.0 \%)$ had more than five years of professional experience.

Table 1 shows the mean perception scores of family-centered care, according to the categorical exploratory variables. It was observed that professionals over 30 years old had a higher mean perception of family-centered care (2.97) when compared to the mean score of younger professionals (2.87). Regarding the level of education, professionals with higher education obtained a lower average score (2.90) in relation to the scores obtained by professionals at a technical level $(3,00)$. However, both were not statistically significant.

The average perception of family-centered care among professionals was $2.93( \pm 0.27)$, the median of 2.90, a maximum score of 3.50, and a minimum of 2.30. Thirty-six professionals $(60.0 \%)$ considered that family-centered care is sometimes practiced in the unit, that is, they presented scores between 2 and 2,9 and 24 professionals (40.0\%) considered that care centered on the family is usually practiced in the unit, with scores between 3 and 3.9. 
Table 1 - Average perception of family-centered care according to categorical exploratory variables

\begin{tabular}{|c|c|c|c|c|c|}
\hline Variables & n (\%) & $\begin{array}{c}\text { Average } \\
\text { score }\end{array}$ & $\begin{array}{l}\text { Standard } \\
\text { Deviation }\end{array}$ & $\begin{array}{c}\text { Average } \\
\text { R }\end{array}$ & $\mathbf{p}$ \\
\hline Age (years old) & & & & & $0.182^{*}$ \\
\hline 25 to 30 & $21(35.0)$ & 2.87 & 0.27 & 2.85 & \\
\hline$>30$ & $39(65.0)$ & 2.97 & 0.26 & 2.95 & \\
\hline Education & & & & & $0.156^{*}$ \\
\hline Complete High school & $22(36.7)$ & 3.00 & 0.27 & 2.98 & \\
\hline Completer Higher Education & $38(63.3)$ & 2.90 & 0.27 & 2.85 & \\
\hline Time of experience (years) & & & & & $0.651^{\dagger}$ \\
\hline Up to 5 & $18(30.0)$ & 2.95 & 0.19 & 2.88 & \\
\hline$>5$ & $42(70.0)$ & 2.93 & 0.30 & 2.90 & \\
\hline \multicolumn{6}{|l|}{ Profession } \\
\hline Nursing team & $34(56.7)$ & 2.96 & 0.25 & 2.93 & $0.332^{*}$ \\
\hline Other professionals & $26(43.3)$ & 2.90 & 0.29 & 2.85 & \\
\hline
\end{tabular}

Table 2 shows the mean scores, standard deviation, maximum and minimum scores for domains. There were no differences in perceptions between domains and mean scores ranged from 2.92 to 2.95 .

Table 2 - Distribution of mean perception scores of family-centered care according to respect, collaboration, and support domains

\begin{tabular}{|c|c|c|c|c|}
\hline Variables & Average score & $\begin{array}{l}\text { Standard } \\
\text { Deviation }\end{array}$ & Minimum & Maximum \\
\hline Respect & 2.92 & 0.37 & 2.00 & 3.83 \\
\hline Collaboration & 2.95 & 0.33 & 2.11 & 3.67 \\
\hline Support & 2.92 & 0.42 & 2.00 & 3.80 \\
\hline
\end{tabular}

\section{Discussion}

The limitations of the study are because it is a cross-sectional design hindering to identify cause and effect relationships and the limited number of institutions participating in the study. These limitations do not invalidate the results of the research but indicate the need for future studies.

In this research, most professionals realize that family-centered care is sometimes practiced in the unit. Thus, a study that aimed to evaluate the effects of the implementation of the Patient and Family Centered Care Model on the perception of parents and health professionals in a neonatal unit corroborates the results presented in identifying that the average perception of centered care in the family among professionals increased by $30.0 \%$ after intervention, however, remaining between 2 and 2.9. Thus, the relevance of training actions is highlighted to sensitize professionals to the assumptions of the philosophy of family-centered $\operatorname{care}^{(7)}$.

On the other hand, an international study that aimed to compare the perception of family-centered care among parents and health professionals, from the same scale, showed a perception of the team with a mean score of 3.14 , that is, a better perception when compared with the results of this study ${ }^{(12)}$. The difference between the results of the studies may be a reflection of the innumerable challenges experienced by Brazilian health professionals in the working conditions.

In this perspective, a study that qualitatively explored the perspective of nurses in the family-centered care revealed that the difficulties to implement this care model are related to the low collaboration among professionals, the lack of permanent education programs that address this issue and the Barriers of the institutions ${ }^{(13)}$. The authors also point out the challenge of effective communication between professionals, as well as between professionals and the family. They affirm that communication enables the creation of bonds and is one of the fundamental principles of family-centered care.

Although better perceptions were observed among professionals over thirty years old and with a high school education, this study did not present statistically significant differences between the outcome variable and the independent variables. However, an international study that aimed to relate the care offered to children and their families, from the perspective of family-centered care, with variables characterizing health professionals, identified that family-centered perception of care scores are significantly different among nursing professionals and physicians, besides the stating that there is a correlation between the age 
of professionals, number of children and educational level ${ }^{(14)}$. In this perspective, the continuous education and the continuous support of the institution are indispensable for the effective preparation of the professionals ${ }^{(7)}$.

The professionals' perceptions regarding the respect, collaboration, and support domains remained similar, with mean scores ranging from 2.92 to 2.95. However, in an international study, there was a difference in the perceptions between domains. Thus, the support domain presented smaller scores when compared to the respect and collaboration domain ${ }^{(12)}$. Therefore, the study emphasizes the importance of strengthening the emotional support offered to families.

Although there were differences observed between the professionals' perceptions in the different studies, the conception prevails that family-centered care, based on actions that respect the preferences, needs, and values of family members, is essential for the development of an effective care plan ${ }^{(15)}$. Awareness raising, training of professionals and teamwork are important, as well as the elaboration of assistance protocols that enhance the reception and empowerment of the family ${ }^{(15-16)}$.

Finally, these results can subsidize the planning of actions of permanent education to potentiate behavioral changes. However, new studies are recommended to identify and analyze the qualitative perception of professionals regarding family-centered care.

\section{Conclusion}

A perception of care far from the recommendations of extended care that aggregate the child and his/her family was identified, that is, the professionals considered that the care centered in the family sometimes is practiced in the unit. The results did not show statistically significant differences between the mean perception scores of family-centered care and the characterization variables of the team, and also did not in- dicate differences in perception between the domains of respect, collaboration, and support.

\section{Collaborations}

Sampaio AA contributed to the design of the study, data collection, and interpretation. Zonta JB and Ferreira FY contributed writing and critical review of intellectual content. Okido ACC contributed in the final approval of the version to be published.

\section{References}

1. Arrué AM, Neves ET, Magnago TSBDS, Cabral IE, Gama,SGND, Hökerberg YHM. Translation and adaptation of the Children with Special Health Care Needs Screener to Brazilian Portuguese. Cad Saúde Pública. 2016; 32(6):e30215. doi: http:// dx.doi.org/10.1590/0102-311X00130215

2. Kuo D, Goudie A, Cohen E, Houtrow A, Agrawal R, Carle AC, Wells N. Inequities in health care needs for children with medical complexity. Health Aff. 2014; 33(12):2190-98. doi: http://dx.doi. org/10.1377/hlthaff.2014.0273

3. Okido ACC, Pina JC, Lima RAG. Factors associated with involuntary hospital admissions in technology-dependent children. Rev Esc Enferm USP. 2016; 50(1):29-35. doi: http://dx.doi. org/10.1590/S0080-623420160000100004

4. Zanello E, Calugi S, Rucci P, Pieri G, Vandini S, Faldella G, et al. Continuity of care in children with special healthcare needs: a qualitative study of family's perspectives. Ital J Pediatr. 2015; 41:19. doi: http://dx.doi.org/10.1186/s13052-0150114-x

5. Okido ACC, Pizzinacco TMP, Furtado MCC, Lima RAG. Technology-dependent children: the maternal care experience. Rev Esc Enferm USP. 2012; 46(5):1066-73. doi: http://dx.doi. org/10.1590/S0080-62342012000500005

6. Pontes EP, Couto DL, Lara HMS, Santana JCB. Nonverbal communication in the pediatric intensive care unit: perception of the multidisciplinary team. Rev Min Enferm. 2014; 18(1):152-7. doi: http://dx.doi.org/10.5935/1415-2762.20140012 
7. Balbino FS, Balieiro MM, Mandetta MA. Measurement of Family-centered care perception and parental stress in a neonatal unit. Rev LatinoAm Enfermagem. 2016; 24(1):e2753. doi: http:// dx.doi.org/10.1590/1518-8345.0710.2753

8. Coyne I. Families and health-care professionals' perspectives and expectations of family-centred care: hidden expectations and unclear roles. Health Expect. 2015; 18(5):796-808. doi: http:// dx.doi.org/10.1111/hex.12104

9. Silva TON, Alves LB, Balieiro MM, Mandetta MA, Tanner A, Shields L. Cross-cultural adaptation of an instrument to measure the family-centered care. Acta Paul Enferm. 2015; 28(2):107-12. doi: http:// dx.doi.org/10.1590/1982-0194201500019

10. Beheshtipoor N, Shaker Z, Edraki M, Razavi M, Zare N. The effect of family-based empowerment program on the weight and length of hospital stay of preterm infants in the neonatal intensive care unit. Galen Med J [Internet]. 2013 [cited 2017 Apr. 12]; 2(3):114-9. Avaliable from: http://www.sid. ir/en/VEWSSID/J_pdf/5054620130301.pdf

11. Polit DF, Beck TB. Fundamentos de Pesquisa em Enfermagem: avaliação de evidências para a prática de enfermagem. Porto Alegre: Artmed; 2011.
12. Gill FJ, Pascoe E, Monterosso L, Young J, Burr C, Tanner A, Shields L, et al. Parent and staff perceptions of family-centered care in two Australian children's hospitals. EJPCH [Internet]. 2014 [cited 2017 Apr. 12]; 1(2):317-25. Available from: http://researchonline.nd.edu.au/nursing article/77/

13. Correa AR. Andrade AC, Manzo BF, Couto DL, Duarte ED. The family-centered care practices in newborn unit nursing perspective. Esc Anna Nery. 2015; 19(4):629-34. doi: http://dx.doi. org/10.5935/1414-8145.20150084

14. Shields L, Mamun AA, Pereira S, O’Nions P, Chaney G. Measuring family centred care: working with children and their parents in a tertiary hospital. Int J Pers Cent Med. 2011; 1(1):155-60. doi: http://dx.doi.org/10.5750/ijpcm.v1i1.41

15. Balbino FS, Meschini GFG, Balieiro MMFG, Mandetta MA. Percepção do cuidado centrado na família em unidade neonatal. Rev Enferm UFSM. 2016; 6(1):84-92. doi: http://dx.doi. org/10.5902/2179769216340

16. Silva TRG, Manzo BF, Faria FCC, Silva PM. Family-centered care from the perspective of nurses in the Neonatal Intensive Care Unit. Rev Rene. 2016; 17(5):643-50. doi: http://dx.doi. org/10.15253/2175-6783.2016000500009 